\title{
504.054
}

\author{
- $\operatorname{epx} \mathbf{y}$ \\ ьвівський н ціон льний університет імені в н \\ вул. . орошенк , 41, м. ввів, 79000, кр їн
}

озглянуто вплив хімічних з бруднюв чів довкілля н здоров'я людини. х р ктеризов но пов'яз ні з цим види 3 хворюв нь. крему ув гу приділено кр їні, де виділено низку медикогеогр фічних регіонів.

лючові слов : здоров’я людини, хімічні з бруднюв чі довкілля, медико-геогр фічні регіони.

доров'я людини можн н зв ти одним з основних екологічних критеріїв якості н вколишнього середовищ . ост нніми д ними , вплив з бруднення довкілля н здоров'я людей ст новить $25 \%$.

плив хімічних речовин н орг нізм людини є зн чним. д ними міжн родної орг ніз ції вропейського союзу виробників хімічних речовин, промисловість виробляє пон д 11 тис. хімік тів, з яких близько 3 тис. ст новлять серйозну з грозу не лише для здоров'я людини, й для їі життя. отреби в продукції хімічної промисловості в усьому світі н стільки зросли, що їі світове виробництво, з д ними , оцінюють приблизно в 1,5 трлн дол. повідомляе, що н світовий ринок н дходить близько 100 тис. н йменув нь хімічних речовин і щороку виробляють ще $1000-2000$ нових [4, с. 277].

ьогодні до т ких "н йвпливовіших" чинників н леж ть: хімічні - пестициди (отрутохімік ти), мінер льні добрив , в жкі мет ли, сильнодійні отруйні промислові речовини, дими (у тому числі тютюновий), будівельні м тері ли й побутов хімія. г то iз з зн чених хімічних речовин не розкл д ються протягом трив лого ч су й зд тні н гром джув тися в л нцюг х живлення. еякі речовини довго не виводяться з орг нізму, кумулюючись у тк нин х т орг н х. ерез т ке збільшення концентр ції їхній нег тивний вплив н орг нізм постійно зрост є й посилюється (т к зв ний кумулятивний ефект).

імічні речовини, що з бруднюють природне середовище, дуже різном нітні. лежно від природи, концентр ції, ч су дії н орг нізм людини вони можуть спричинюв ти різні нег тивні н слідки. ороткоч сний вплив невеликих концентр цій т ких речовин може призвести до з п морочення, нудоти, дертя в горлі, к шлю. отр пляння в орг нізм людини великих концентр цій токсичних речовин може спричинити втр ту свідомості, гостре отруєння і н віть смерть. рикл дом подібної дії можуть бути смоги, що утворюються у великих міст х у тиху погоду бо в рійні викиди токсичних речовин промисловими підприємств ми в тмосферу. копичуючись в орг нізмі, хімічні з бруднюв чі виклик ють різні порушення (екоп тології): зміну діяльності ферментних

(C) 
систем, що регулюють процеси обміну, імунологічної ре ктивності, порушення норм льної роботи окремих орг нів т їхніх систем.

міст приблизно 800 речовин у довкіллі в кр їні контролюють іністерство екології і природних ресурсів, іністерство охорони здоров'я, гідрометеорологічн служб , гром дські орг ніз ції. тім, т кий контроль не охоплює н віть третини відомих речовин, небезпечних для людини. онтроль хімічного ст ну середовищ потребує великих фін нсових і м тері льних з тр т, високої кв ліфік ції експертів.

труктур 3 хворюв нь безпосередньо пов'яз н 3 х р ктерними озн к ми викидів промисловості, як перев ж є в певному регіоні. прикл д, кольоров промисловість спричинює, головно, розл д серцево-судинної системи; чорн мет лургія - 3 хворюв ння крові й появу злоякісних утворень, вр ж є орг ни дих ння; хімічн - вплив є н скл д крові, розвиток злоякісних пухлин; з стосув ння пестицидів у сільському господ рстві породжує з хворюв ння орг нів тр влення, обміну речовин, крові тощо. нкологічні з хворюв ння з леж ть від хімічної природи речовини.

йбільшими екоп тологіями вн слідок хімічного з бруднення довкілля були: з бруднення повітря діоксидом сірки і з вислими ч стк ми сірки (смог) у ондоні 1952 р. (3 000 з гиблих ун слідок з хворюв ння серця і легенів); з бруднення рису к дмієм у оямі ( понія) в 50-х рок х ст. (200 осіб з тяжкими симптом ми і 6 г то з легким отруєнням ун слідок хвороб нирок і кісток); з бруднення посівного зерн гекс хлоp ном н південному сході уреччини 1956 р. (200 тяжких вип дків з хворюв ння, 2000 осіб з легким отруєнням ун слідок виникнення неврологічної хвороби); з бруднення риби ртуттю у ін м ті ( понія) 1956 р. (200 тяжких вип дків з хворюв ння, 2000 осіб з легким отруєнням ун слідок виникнення неврологічної хвороби); з бруднення свинцевими 6 рвник ми в у 60-70-х рок х ст. (декільк тисяч хворих ун слідок виникнення немії, порушення психіки і поведінки); з бруднення вершкового м сл біфеніл ми у м. укуок ( понія) 1968 р. (декільк тисяч хворих н шкірні хвороби); з брудненя посівного зерн ртутьметилом в р ку 1972 р. (500 з гиблих, 6500 осіб госпіт лізов них ун слідок неврологічних з хворюв нь); з бруднення середовищ т лієм у ернівцях ( $к р$ їн ) у 80-ті роки ст. (декільк сотень хворих дітей ун слідок лопеції (вип д ння волосся у дітей), з г льн інтоксик ція вн слідок з бруднення середовищ т лієм).

ст ннім ч сом посилил сь ув г ф хівців у г лузі х рчової токсикології до поліхлоров них біфенілів ( ) т діоксинів - стійких хлоров них ром тичних вуглеводнів, які зд тні н копичув тися в орг нізмі людини і перед в тись у х рчових л нцюг х.

крові н селення всієї емлі виявляють усіх ступенів хлоров ності від 2 до 5 мкг н 1 кг м си тіл . йбільшу кількість н копичують риб т рибні продукти, зн чно меншу кількість - молоко і молочні продукти. міст в добовому р ціоні н селення промислово розвинутих кр їн вропи ст новить 1-100 мкг (умовно допустим доз -0,07 мг/кг, з якої спостеріг ють токсичну дію) [3]. опустимі рівні , прийняті у для різних продуктів, колив ються від 0,3 (м'ясо птиці) до 5 мг/кг (ри6 ). остре отруєння ур ж є шкіру, подр знює очі, верхні дих льні шляхи, зміни в печінці, подр знення тр вних, сечовивідних шляхів, головний біль.

здоров'я людей нег тивно вплив ють пестициди. трутохімік ти в процесі з стосув ння можуть потр пляти в повітря, воду, грунт, з бруднюючи х рчові продукти.

отр пляючи у питну воду і продукти х рчув ння, пестициди спричинюють порушення діяльності центр льної нервової, серцево-судинної т інших систем орг нізму, ном лії новон роджених т зниження опірності імунної системи. икорист ння і норми 
витр т пестицидів є різними в кр їні т з ії меж ми. прикл д, до $40 \%$ пестицидів у н с розпилюється в повітря, що к тегорично з боронено в б г тьох кр їн х. понці, н прикл д, пестицид топсин використовують з розр хунку 67 г н 100 л розчину, в н ших інструкціях для спрощення технології, норми визн чені вже в розмірі 100 г н 100 л розчину.

исокі концентр ції нітр тів у питній воді чи продукт х х рчув ння можуть спричинити гострі отруєння людей. ерші озн ки отруєння серед дітей спостеріг ють уже 3 концентр ції 100 мг н 1 л води бо соку. жкі отруєння фіксують у р зі вмісту нітp тів у х рчових продукт х, воді, н поях щон йменше 1200 мг н 1 л бо н 1 кг. ідомо, що нітр ти з тонкої кишки швидко потр пляють у кров і т м відновлюються до нітритів. труєння виник є як н слідок впливу комбін ції нітр тів і нітритів. утливість до нітр тів підвищується з умов гірської місцевості, 3 н явності в повітрі оксиду зоту, ч дного г зу, вуглекислоти т в р зі вжив ння спиртних н поїв. ітр ти х рчових продуктів спричинюють більш вир жені симптоми з боку тр вного к н лу, серцевосудинної т центр льної нервової систем; нітр ти води - з боку серцево-судинної, дих льної т центр льної нервової систем.

ебезпеку для здоров'я людини ст новлять т кож відпр цьов ні г зи двигунів втомобілів, які містять до 200 різних компонентів, б г то з яких - токсичні. н селення вплив ють оксид вуглецю, оксид зоту, вуглеводні, с ж, діоксид сірки, сірчистий нгідрид, сірчистий г 3 т вуглець. р зі 12-хвилинного впливу оксиду вуглецю в

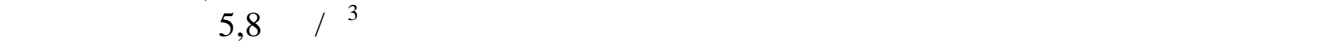
головного мозку. ксиди зоту руйнівно діють н легені людини. винець вр ж є всі орг ни і системи, не тільки вибірково вплив є н нервову систему. ж , як і будь-як тверд речовин, подр знює дих льні шляхи людини, знижує видимість н дорог х, ст є переносником поліциклічних вуглеводнів. вип дку перебув ння людини в середовищі з концентр цією сірчистого г зу 0,01\% спостеріг ють подр знення слизової оболонки горл , 3 н явності $0,04 \%$ діоксиду сірки вже через 3 хв н ст є 3 г льне отруєння орг нізму. бруднення тмосфери вихлипними г з ми втотр нспорту є в гомою причиною виникнення злоякісних пухлин у людей, що підтверджене т кож німецькими вченими. чені, порівнюючи кількість втомобілів зі смертністю від злоякісних пухлин у імеччині, з'ясув ли, що в 1900 р. від р ку легень умир в кожний 30-й, у 1930 - кожний 8-й, у 1971 - кожний 5-й, у 2000 р. - кожний 4-й.

кр їні промислові джерел щорічно викид ють в тмосферу пон д 10 млн т токсичних хімічних сполук, скид ють у водойми 2,5 млрд м ${ }^{3}$ з бруднених стічних вод.

43 міст $x$, де прожив є $30 \%$ н селення кр їни, рівень з бруднення повітряного 6 сейну зн чно перевищує гр ничнодопустимі концентр ції ( ). ст нніми рок ми в міських стічних вод х у 10,8 р з зросл кількість свинцю, у 5,2 р 3 - міді, у 4,8 нікелю, у 3,7 - цинку.

н чне з бруднення довкілля спричиняє хіміз ція сільського господ рств . орічно в грунти кр їни вносять 170 тис. т пестицидів, 150 тис. т мінер льних добрив. ними в грунт н дходить 1800 т свинцю, 400 т к дмію, 2200 т цинку, 200 т міді [5]. ст ннім ч сом з'явилося 6 г то док зів зв'язку між використ нням хімік тів у сільському господ рстві т р ковими з хворюв ннями. пров дження гербіцидів призвело до з бруднення $90 \%$ поверхневих вод. йбільший відсоток вип дків отруєння спричинюють фосфороорг нічні сполуки.

едичн ст тистик свідчить, що з г лом по кр їні з д ними 2006 р. 3 хворюв ність н селення є високою. йбільше, як і в попередні роки, серед н селення поши- 
рені хвороби орг нів дих ння $(25,4 \%)$, системи кровообігу $(20,9)$, нервової системи т орг нів чуття (10,5\%). ише з 2006 р. поширеність хвороб крові т кровотворних орг нів збільшил ся н 9,2 \%, ускл днення в гітності, пологів т післяпологового періоду - н 9,4, хвороб сечост тевої системи - н 5, системи кровообігу - н 4,5, вроджених ном лій - н 4,2\%.

о н йбільш екологоз лежних видів п тології н леж ть лергічні з хворюв ння. 'ясов но, що н формув ння рівня поширення т ких хвороб суттєво вплив ють тмосферні з бруднюв чі з вир женою лергенною дією - льдегіди, біопреп р ти, форм льдегід тощо. ірогідні порушення в рівні з хворюв ності дітей н хвороби цієї групи спостеріг ють вже 3 умов двор зового перевищення гігієнічних норм тивів вмісту з зн чених речовин в тмосферному повітрі. озр хунок відносного ризику розвитку лергічних хвороб з свідчив, що прожив ння в екологічно несприятливих умов $\mathrm{x}$ збільшує ризик розвитку цього виду п тології у 3,5 р 3 .

езв ж ючи н деяке зниження вмісту нтропогенних домішок у н вколишньому середовищі по кр їні з г лом, рівень з бруднення, особливо тмосферного повітря н селених р йонів, є ще досить високим, що нег тивно позн ч ється н ст ні здоров'я, передусім, дітей т підлітків, які є чутливішими до дії будь-яких несприятливих чинників.

кр їн дуже неоднорідн з рівнем екологічного розвитку, ступенем урб ніз ції, способом життя, рівнем медичної допомоги, віково-ст тевим скл дом н селення тощо. мовно територію кр їни можн розділити н п'ять медико-демогр фічних регіонів: північно-східний, південний, південно-східний, центр льний, з хідний $[1,2]$. ст ннім десятиріччям рівень 3 хворюв ності в кр їні збільшився н 21,5\%. структурі 3 г льної з хворюв ності н селення помітнішими ст ють хвороби, у виникненні яких провідну роль відігр ють екзогенні чинники, що пов'яз ні з порушенням т небезпечним з брудненням довкілля. егіон льний н ліз з хворюв ності свідчить про те, що

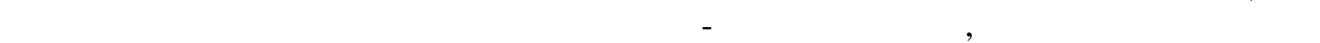
тут є т кі з хворюв ння: новоутворення, хвороби орг нів дих ння, психічні з хворюв ння, вроджені ном лії. південному регіоні н першому місці - хвороби орг нів дих ння, нервової системи й орг нів чуття, порушення кровообігу. структурі смертності в північно-східному регіоні основне місце посід ють судинні вр ження мозку, новоутворення, тр вми, отруєння т нещ сні вип дки. селення центр льного регіону н йч стіше хворіє н новоутворення, хвороби крові т кровотворних орг нів, ендокринні з хворюв ння тощо. чевидно, що, крім інших несприятливих чинників довкілля, вл стивих цьому регіону, в гомим $є$ р ді ційне з бруднення. ля з хідного регіону х р ктерний високий рівень 3 хворюв ності орг нів дих ння, тр влення, кровообігу, нервової системи т орг нів чуття тощо.

тже, н ліз здоров'я людини з регіон ми виявляє повну їхню з лежність від н пряму господ рського розвитку т екологічного ст ну довкілля.

1. $\quad$ н новський . . кр їн . кологічн небезпек . 1:3000 000. . . , 2001.

2. $\quad$ новський . . кр їн . колого-економічне зонув ння території. $1: 3000000 . \quad$. , 2001 .

3. онч ренко . ., ойчук . . кологія людини / ред. . . . очубей. уми, $\quad . \quad$ н-тськ книг , нягиня льг , 2005. 400 с.

4. ценко . . ігієн і екологія людини. ьвів: фіш , 2000. 248 с. 
5. ціон льн доповідь кр їни про ст н н вколишнього природного середовищ в кр їні 3 2006 рік. іністерство охорони н вколишнього природного середовищ кр їни. ., 2007. 228 с.

\section{HEALTH OF INDIVIDUAL AND CHEMICAL POLLUTION OF ENVIRONMENT: GLOBAL AND REGIONAL ASPECTS}

\section{O. Perkhach}

Ivan Franko National University of Lviv, . Doroshenko St., 41, UA - 79000 Lviv, Ukraine

The influence of chemical pollution of environment on a health of individual was examined. It were characterized the related types of diseases. It was focused separate attention on Ukraine, where a number of medicogeographical regions was selected.

Key words: health of individual, chemical pollution of environment, medicogeographical regions.

\section{- $\operatorname{epx} \mathbf{y}$}

ьвовский н цион льный университет имени в н

ул. . орошенко, 41, г. ьвов, 79000, кр ин

ссмотрено влияние химических з грязнителей окруж ющей среды н здоровье человек . x p ктеризов но связ нные с этим виды з болев ний. собое вним ние уделено кр ине, где выделено ряд медико-геогр фических регионов.

лючевые слов : здоровье человек, химические з грязнители среды, медико-геогр фические регионы.

т ття н дійшл до редколегії 17.09.2009

рийнят до друку 20.09.2009 